Article

\title{
Snow Impurities in the Central Pyrenees: From Their Geochemical and Mineralogical Composition towards Their Impacts on Snow Albedo
}

\author{
Jorge Pey ${ }^{1,2, * \mathbb{C}}$, Jesús Revuelto ${ }^{2}{ }^{\mathbb{D}}$, Natalia Moreno $\left.{ }^{3}{ }^{(}\right)$, Esteban Alonso-González ${ }^{2}$, \\ Miguel Bartolomé ${ }^{4}\left(\mathbb{D}\right.$, Jesús Reyes ${ }^{5}$, Simon Gascoin ${ }^{6}(\mathbb{D})$ and Juan Ignacio López-Moreno ${ }^{2}(\mathbb{D}$ \\ 1 Aragonese Foundation for Research and Development (ARAID), 50018 Zaragoza, Spain \\ 2 Pyrenean Institute of Ecology, Spanish Research Council (IPE-CSIC), 50059 Zaragoza, Spain; \\ jrevuelto@ipe.csic.es (J.R.); e.alonso@ipe.csic.es (E.A.-G.); nlopez@ipe.csic.es (J.I.L.-M.) \\ 3 Institute of Environmental Assessment and Water Research, Spanish Research Council (IDAEA-CSIC), \\ 08034 Barcelona, Spain; natalia.moreno@idaea.csic.es \\ 4 National Museum of Natural Sciences, Spanish Research Council (MNCN-CSIC), 28006 Madrid, Spain; \\ mbart@mncn.csic.es \\ 5 Geological Survey of Spain (IGME), 28760 Madrid, Spain; j.reyes@igme.es \\ 6 Centre d'Etudes Spatiales de la Biosphère, UPS/CNRS/IRD/INRAE/CNES, 31000 Toulouse, France; \\ simon.gascoin@cesbio.cnes.fr \\ * Correspondence: jorge.pey@ipe.csic.es
}

Received: 7 August 2020; Accepted: 1 September 2020; Published: 2 September 2020

\begin{abstract}
The aim of this work is to understand aerosol transfers to the snowpack in the Spanish Pyrenees (Southern Europe) by determining their episodic mass-loading and composition, and to retrieve their regional impacts regarding optical properties and modification of snow melting. Regular aerosol monitoring has been performed during three consecutive years. Complementarily, short campaigns have been carried out to collect dust-rich snow samples. Atmospheric samples have been chemically characterized in terms of elemental composition and, in some cases, regarding their mineralogy. Snow albedo has been determined in different seasons along the campaign, and temporal variations of snow-depth from different observatories have been related to concentration of impurities in the snow surface. Our results noticed that aerosol flux in the Central Pyrenees during cold seasons (from November to May, up to $12-13 \mathrm{~g} \mathrm{~m}^{-2}$ of insoluble particles overall accumulated) is much higher than the observed during the warm period (from June to October, typically around 2.1-3.3 $\mathrm{g} \mathrm{m}^{-2}$ ). Such high values observed during cold seasons were driven by the impact of severe African dust episodes. In absence of such extreme episodes, aerosol loadings in cold and warm season appeared comparable. Our study reveals that mineral dust particles from North Africa are a major driver of the aerosol loading in the snowpack in the southern side of the Central Pyrenees. Field data revealed that the heterogeneous spatial distribution of impurities on the snow surface led to differences close to 0.2 on the measured snow albedo within very short distances. Such impacts have clear implications for modelling distributed energy balance of snow and predicting snow melting from mountain headwaters.
\end{abstract}

Keywords: African dust; atmospheric deposition; snow albedo; iron oxides; Mediterranean climate

\section{Introduction}

Aerosols are studied because of their impacts on human health [1,2], ecosystems [3,4], and climate $[5,6]$. Once completed their atmospheric cycle, aerosols are transferred to earth surfaces. Physical and chemical properties of these particles and the media in which they are deposited explain 
the sort of variety of derived effects. Thus, the deposition of certain aerosol types on ice and snow surfaces may amplify warming processes associated to climate change. The snow darkening caused by black carbon [7-9] or mineral dust [10-12] deposition encompasses a decrease of albedo, overall modifying the radiative balance of these surfaces and consequently affecting the regional climate. These phenomena have a clear impact over the hydrological cycle, as snow melting processes can be accelerated [12-16]. On the other hand, other studies have pointed out that aerosol cooling in the atmosphere could compensate partially the positive radiative forcing over snow [17-20]. Many studies have highlighted the critical role of snow albedo on the energy balance of the snowpack, directly affecting melt rates, snow duration and the hydrological regime of snow dominated basins. Snow in the Pyrenees is critical for the water resources availability of the dry lowlands [21] and a deeper understanding of the effect of snow impurities on snow is necessary for improving estimations on the amount and timing of the spring freshet.

In Southern Europe, natural dust blowing from North Africa is responsible of a significant part of the atmospheric pollution over certain regions [22,23]. Dusty air masses from North Africa are detected one third of the annual days over the southernmost parts of Europe [23], causing an important number of exceedances of air quality standards [22]. The presence of nutrients [24] and microorganisms [25] in dust aerosols could explain some of the derived effects. Thus, African dust aerosols impact negatively human health in Mediterranean countries and the causes for these outcomes are still under debate [26]. Likewise, African dust deposition have different impacts on terrestrial and aquatic ecosystems $[24,27,28]$. Our hypotheses consider that the effects of African dust deposition in Southern Europe go beyond the listed ones. Actually, we do observe a recurrent snow darkening, generally at the end of the winter season, and we pondered whether or not atmospheric deposition was behind this phenomenon.

The Pyrenees range is the natural barrier between France and Spain, which extends over $430 \mathrm{~km}$ from its western side toward the eastern side, with near 130 mountain summits over $3000 \mathrm{~m}$ a.s.l. mainly located in their central part. African dust air masses reach this mountain barrier around $10 \%$ of the annual days [23], but dust deposition is strongly magnified in this region with respect to other areas located hundreds of kilometers southwards [29]. In this article we discuss about the relevance of aerosol inputs in the Central Pyrenees, their chemical-mineralogical composition, the role of desert dust in the observed fluxes, and their inter-annual variations. Furthermore, we study the relationship between the concentration of impurities on the snow surface, many of them acting as light absorbing particles (LAPs) [12] and the observed inter-seasonal and intra-seasonal snow albedo variations.

\section{Experiments}

\subsection{Study Area and Period}

The study area for this work is located in the Central Pyrenees (Spain), in the Huesca province (Figure 1). Atmospheric deposition samples were collected uninterruptedly at the Ordesa and Monte Perdido National Park (ORD), at an elevation of $1200 \mathrm{~m}$ a.s.l. Details about site characteristics, sample collection and laboratory processes are given in [29]. Snow measurements were conducted in the nearby Izas experimental catchment, at an elevation of $2050 \mathrm{~m}$ a.s.l., which is located $35 \mathrm{~km}$ to the NW of ORD. Atmospheric deposition at both sites has been assumed as comparable given the relatively short distance between these sites. Nevertheless, small differences may occur under certain atmospheric conditions, especially during micro-scale phenomena such as thunderstorms. Observations presented here were obtained during the 2016-2017, 2017-2018, and 2018-2019 snow seasons, respectively characterized by medium, high, and moderate snow accumulations when compared to the database of snow depth observations available in Izas experimental catchment [30]. 


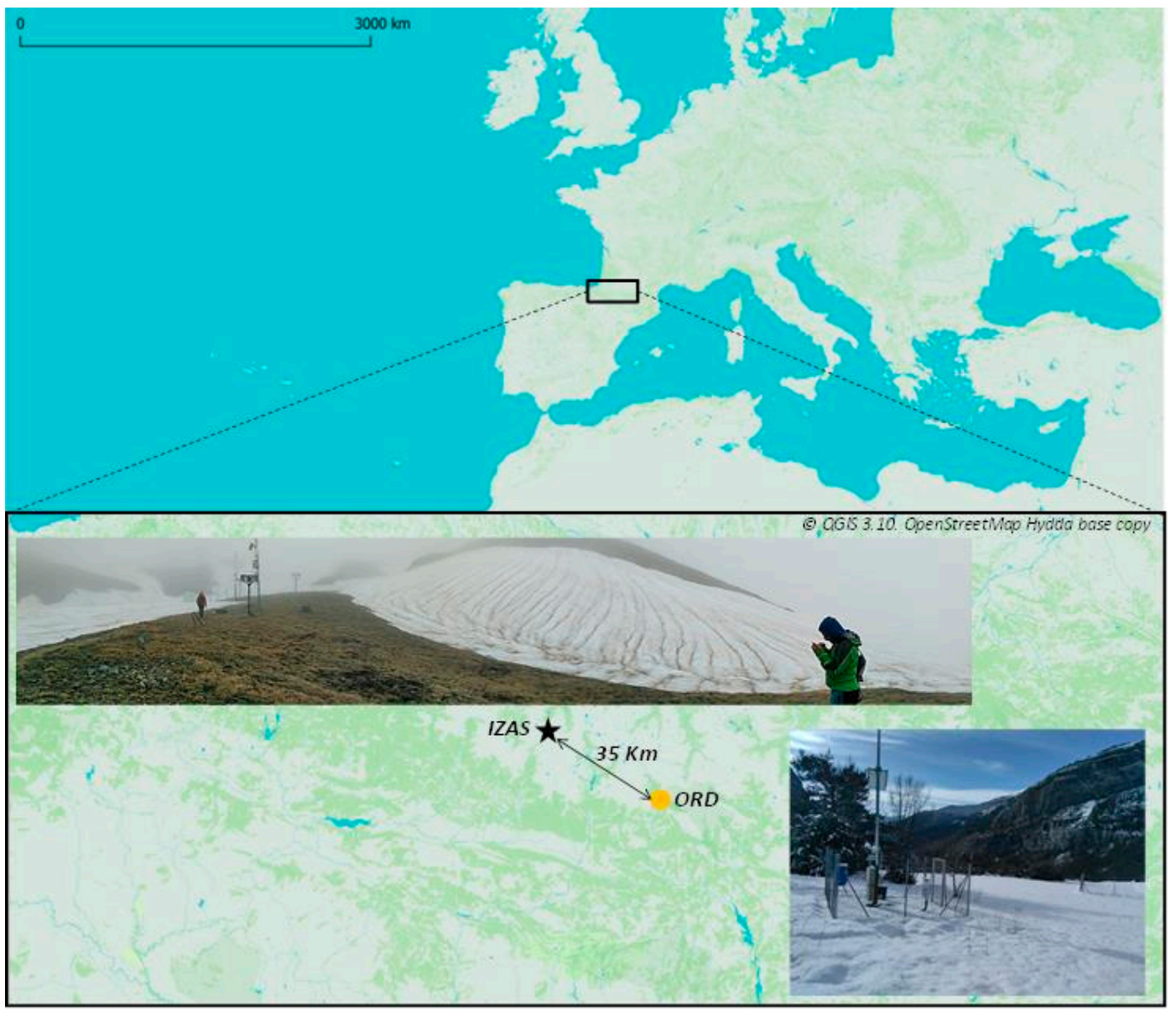

Figure 1. Location of the study area, situation of the monitoring sites (Izas and Ordesa and Monte Perdido National Park-ORD) and photos of the monitoring sites. Photos taken by J. Pey: Izas (upper part), on 29 May 2018; Ordesa (bottom part), on 9 January 2018.

\subsection{Sample Collection}

Bulk atmospheric deposition samples were collected periodically. Basically, our atmospheric collector is made up by a funnel acting as the collection surface, a $10 \mathrm{~L}$ container to recover the precipitation, and tubing to connect these two parts. These elements are mounted in a dark box in order to avoid biological blooms. Once in the laboratory, a double filtration procedure was performed. The first step was conducted to remove large particles such as insects or vegetable debris; whereas the second one was dedicated to accumulate the insoluble atmospheric particles onto quartz microfiber filters. From each sample, at least two filters (previously conditioned and weighted under controlled conditions) were obtained, one for geochemical analyses and a second one for other determinations. From filters, the deposition flux of insoluble particles was obtained, considering the mass difference between the final filters and their respective blanks, and taking into account the collection surface. Fluxes are expressed in $\mathrm{mg} \mathrm{m}^{-2}$ when referring to single periods, or in $\mathrm{g} \mathrm{m}^{-2}$ when denoting annual or seasonal fluxes. Aliquots from each sample were obtained and subsequently analyzed. Methodological details and results from these analyses are given in [29]. By taking into account the accumulated volume, the collection surface and the concentration of soluble-inorganic species, the related deposition flux of soluble inorganic species was obtained for each monitoring period. Extended details about the determination of aerosol fluxes are provided in [25].

Complementarily to the monitoring of atmospheric deposition, snow samples were taken during the intense African dust events that occurred in November 2016 and February 2017. The monitoring area for the snow sampling was next to the ORD site, but at $2200 \mathrm{~m}$ a.s.l, in the proximity of the Marboré 
Lake. To this end, a snow pit was dug to locate the dust layer. Once identified, a $10 \times 10 \times 3 \mathrm{~cm}$ section was taken. Samples were subjected to the same procedures as atmospheric deposition samples. A comparative analysis between snow samples (few hours of dust-rich precipitation) and atmospheric deposition samples (15-days of atmospheric fallout) are presented.

\subsection{Analytical Determinations}

Filters dedicated to geochemical analyses were subjected to different laboratory processes in the Geological Survey of Spain facilities, in Tres Cantos-Madrid (Spain). Thus, a $\frac{3}{4}$ section of each filter was used to quantify the concentration of major and trace elements. To this end, an acid digestion following the procedures described in [31] was conducted. Briefly, each filter section was completely digested in a $\mathrm{HF}: \mathrm{HNO}_{3}: \mathrm{HClO}_{4}$ mixture, driven to complete dryness, re-dissolved in $\mathrm{HNO}_{3}$ ( $5 \%$ concentration), and finally analyzed by inductively coupled plasma atomic emission spectroscopy and inductively coupled plasma mass spectrometry. Concentrations of major ( $\mathrm{Al}, \mathrm{Ca}, \mathrm{Fe}, \mathrm{K}, \mathrm{Mg}, \mathrm{Na}, \mathrm{Mn}, \mathrm{Sr}$, and $\mathrm{Ti}$ ) and trace (Ag, $\mathrm{As}, \mathrm{Ba}, \mathrm{Be}, \mathrm{Cd}, \mathrm{Co}, \mathrm{Cr}, \mathrm{Cu}, \mathrm{Mo}, \mathrm{Ni}, \mathrm{Pb}, \mathrm{Sb}$, Se, Th, Tl, U, V, and $\mathrm{Zn}$ ) elements were obtained. Blank filters were analyzed together with each set of samples in order to remove the filter contribution. Only elements displaying concentrations above the limit of quantification are shown in this work. $\mathrm{SiO}_{2}$ concentrations were reconstructed from $\mathrm{Al}_{2} \mathrm{O}_{3}$ by applying the experimental factor of 2.5 obtained during African dust outbreaks in SW Europe [32]. Some of the elements/compounds were grouped together to account for the overall mineral dust content: $\mathrm{SiO}_{2}, \mathrm{Al}_{2} \mathrm{O}_{3}, \mathrm{Ca}, \mathrm{K}, \mathrm{Na}, \mathrm{Mg}, \mathrm{Fe}, \mathrm{Ti}$, $\mathrm{Mn}$, and $\mathrm{Sr}$, as in [31].

Organic carbon and elemental carbon were determined in the IDAEA-CSIC laboratories, in Barcelona (Spain) by means of a thermo-optical SUNSET analyzer (Sunset Laboratory Inc., Tigard, OR, USA) in a $0.196 \mathrm{~cm}^{2}$ subsection of each filter, following EUSAAR_2 temperature protocol [33]. Given the remoteness of the sampling sites, organic carbon concentrations were converted into organic matter by applying a 2.1 factor, as in [34].

Once the chemical composition is unveiled, the unaccounted mass corresponds to the difference between the insoluble mass and the sum of all chemical elements and/or compounds.

\subsection{Mineralogy of African Dust Samples}

Mineralogical analyses of the dust samples were performed by X-ray diffraction (XRD) in the IDAEA-CSIC laboratories, in Barcelona (Spain), by using a Bruker D8 Advance powder diffractometer with monochromatic $\mathrm{Cu} \mathrm{K} \alpha$ radiation $(\lambda=1.5405 \AA)$ operated at $40 \mathrm{KV}$ and $40 \mathrm{~mA}$. The primary parallel X-ray beam was generated by a Göbel mirror and the scattered beam was analyzed by a Sol-X detector. The diffractograms were obtained from $4^{\circ}$ to $60^{\circ}$ of $2 \theta$ with a step size of $0.05^{\circ}$ and a counting time of $3 \mathrm{~s} / \mathrm{step}$. The crystalline phase's identification was carried out by means of the EVA software (Bruker), which feeds with the ICDD (International Centre for Diffraction Data) database [35].

\subsection{Distributed Snow Albedo Observations}

Broadband snow surface albedo was retrieved with a CMA 6 Kipp \& Zonen albedometer with a spectral range covering from 350 to 2500 nanometers [36]. The albedo was computed through the ratio between upward and downward radiation. For each experimental campaign ( 2 in 2016-2017 and 3 in 2018-2019) conducted in Izas, between 4 and 16 distributed observations on different locations of the albedo were obtained. Unfortunately, it was not possible to perform usable measurements during the snow season 2017-2018 because of the harsh weather conditions during most of the melting season. On each of these locations snow samples of the first $5 \mathrm{~cm}$ of the snowpack were collected for quantifying the amount of impurities' concentration and a later characterization of the mineral deposits concentration. To this end, snow samples were subjected to the same laboratory filtration procedures as explained in Section 2.2. The concentration of impurities determined in snow samples includes those components acting as LAPs, although their discrimination has not been performed in these samples. 
On 21 May 2019, snow reflectance was also measured with a field spectroradiometer to assess the impact of impurities on snow spectra. We used an ASD FieldSpec 4 Hi-Res (Malvern Panalytical, Malvern, UK) with a spectral range of 350-2500 nm and a spectral resolution of $3 \mathrm{~nm}$ in the spectral region 350 to $1000 \mathrm{~nm}$ and $8 \mathrm{~nm}$ above. The measurements were taken with a pistol grip fore optic with a $25^{\circ}$ field of view. First, the incident irradiance was measured on a diffuse white reflectance reference panel (spectralon) with the same fore optic (i.e., white reference). Then, the reflected radiance from the snow surface was acquired in two transects of $20 \mathrm{~m}$ each at $2 \mathrm{~m}$ interval. The pistol grip was held at arm's length heading in the sun's direction to avoid casted shadows from the operator. The white reference was repeated every $10 \mathrm{~min}$ which was deemed sufficient given the total absence of clouds on that day. We use here the raw spectra without normalizing or adjusting for the surface slope. Given that measurements were made over gentle slopes at midday with sun zenith angle near $30^{\circ}$, terrain slope is not expected to strongly distort the relative shapes of the spectra [37].

\subsection{Snow Depth, Temperature, Precipitation, and Albedo in Izas Catchment}

Izas Experimental Catchment is equipped with an automatic weather station that acquires every 10 min different meteorological variables, comprising among others, surface air temperature, surface albedo (broadband), total precipitation, and snow depth [30], as shown in Figure 2. From these observations it was computed the mean, the maximum, and the mean air temperatures. Also the daily broadband albedo was calculated as the average of the incident versus reflected radiation ratio while more than $10 \mathrm{~W} / \mathrm{m}^{2}$ were observed in the downward sensor (during the day). Finally, the daily mean snow depth and total daily precipitation were obtained.
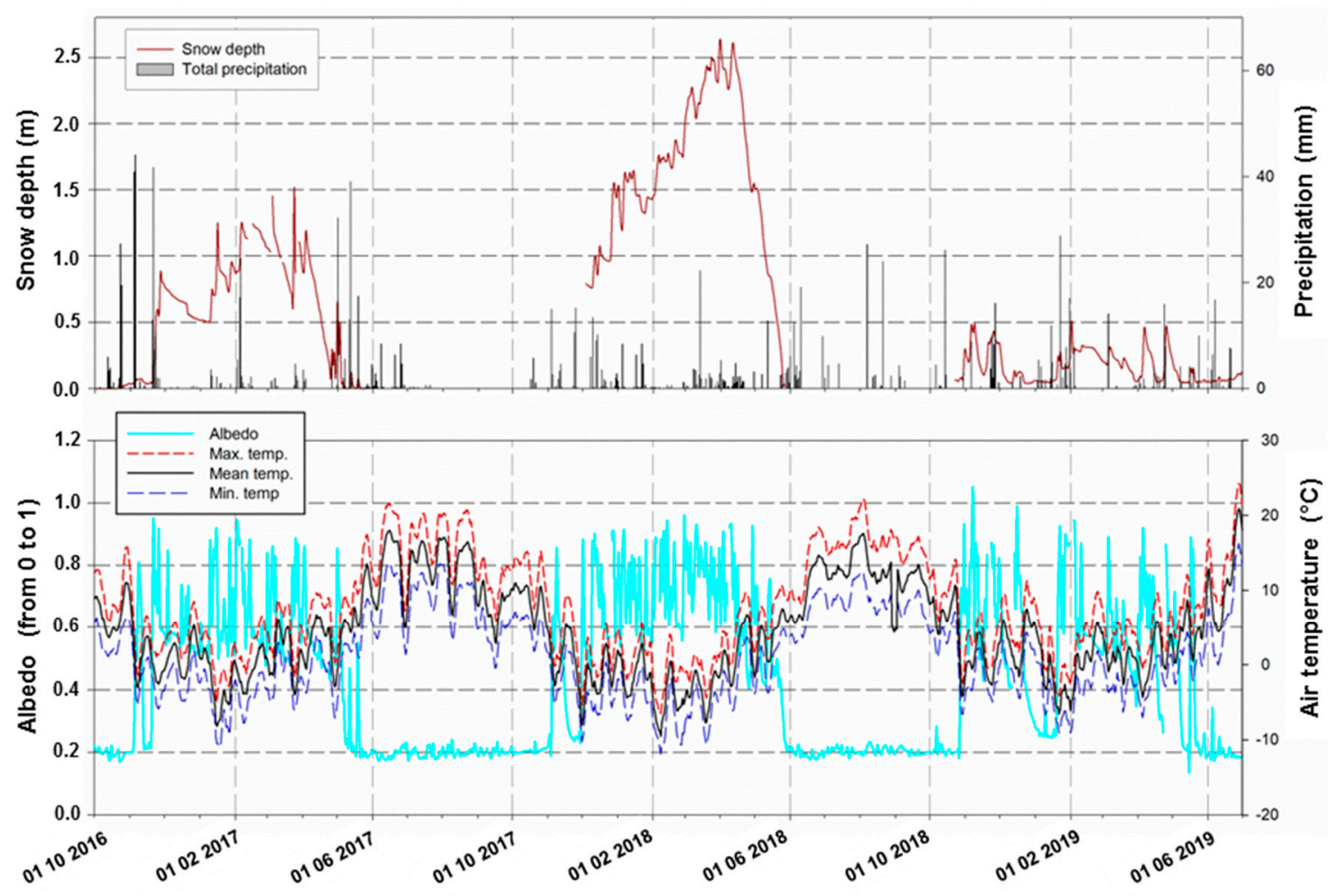

Date

Figure 2. Temporal evolution of main meteorological variables observed at the automatic weather station of Izas Experimental Catchment. Upper panel shows, the snow depth and total precipitation observed during the study period. Bottom panel shows, mean, maximum, and minimum air temperature (averages in 5 days intervals) and surface albedo. 


\section{Results}

\subsection{Atmospheric Deposition: Seasonal Variations and Geochemical and Mineralogical Composition}

\subsubsection{Aerosol Fluxes and Seasonal Variations: Impact of African Dust}

Aerosol deposition in the period June 2016-June 2019 in the Central Pyrenees has been characterized by relatively stable fluxes during the warm season (from June to October), ranging from 2.1 to $3.3 \mathrm{~g} \mathrm{~m}^{-2}$ for the insoluble fraction, and 3.5 to $5.1 \mathrm{~g} \mathrm{~m}^{-2}$ to the soluble fraction (Figure 3). In contrast, aerosol fluxes were much higher during 2016-2017 and 2017-2018 cold seasons, rising to 11.7 to $13.0 \mathrm{~g} \mathrm{~m}^{-2}$ for the insoluble fraction, and 10.0 to $10.3 \mathrm{~g} \mathrm{~m}^{-2}$ to the soluble fraction, whereas they were significantly lower in 2018-2019 cold season. High aerosol fluxes observed during the cold season were driven by the impact of severe African dust episodes (see [29] for further details). In our case, a single event occurred in April 2018 transferred $10.6 \mathrm{~g} \mathrm{~m}^{-2}$ of insoluble particles. November 2016 and February 2017 dust events deposited up to $7.6 \mathrm{~g} \mathrm{~m}^{-2}$ and $4.5 \mathrm{~g} \mathrm{~m}^{-2}$ of insoluble particles, respectively. The lack of severe dust episodes during the 2018-2019 cold period explains the six-times seasonal reduction regarding the insoluble flux with respect to previous years.

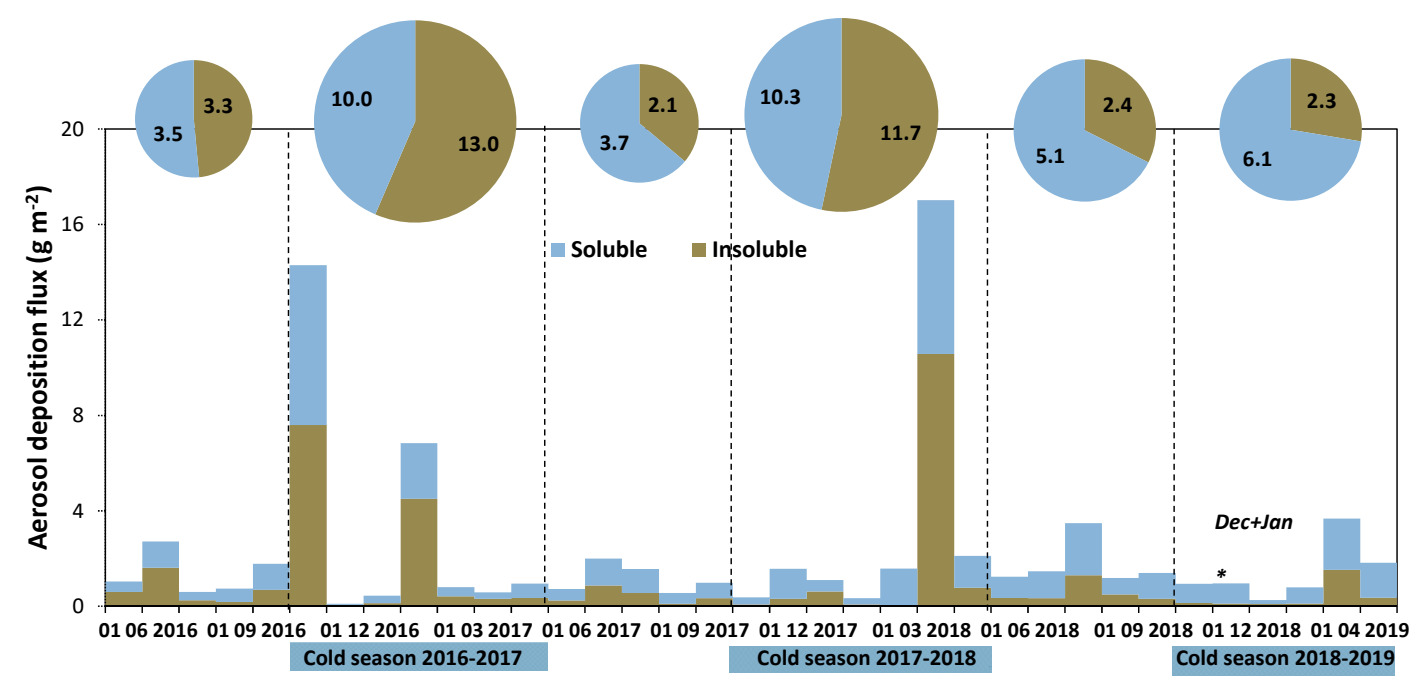

Figure 3. Monthly and seasonal aerosol soluble and insoluble fluxes $\left(\mathrm{g} \mathrm{m}^{-2}\right)$ recorded in the Ordesa and Monte Perdido National Park (Central Pyrenees, Spain) from June 2016 to June 2019. * stands for a combined two-month sample instead of a 30-days sample.

\subsubsection{Geochemical Composition of Insoluble Particles}

In this section we focus on the chemical composition of airborne particles deposited in the ORD site during cold seasons. Aerosol deposition dominated the overall budget during the first two, while no significant episodes occurred in the 2018-2019 season. As a result, chemical composition changed dramatically, as depicted in Figure 4. 2016-2017 and 2017-2018 cold seasons were clearly dominated by mineral dust deposition (71-75\%), followed by organic matter (10-17\%) and soot (1-3\%), the rest of the aerosol mass being unaccounted. On the contrary, the 2018-2019 cold season registered lower aerosol fluxes, radically different in composition, in this case shifted to organic matter (67\%), soot (7\%), and mineral dust (5\%). 
2016-2017

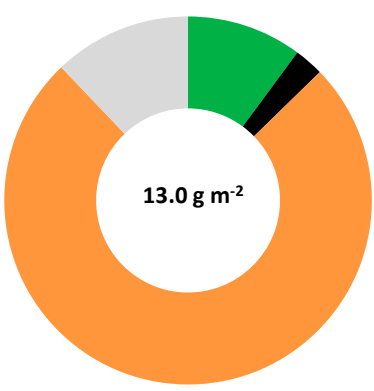

2017-2018

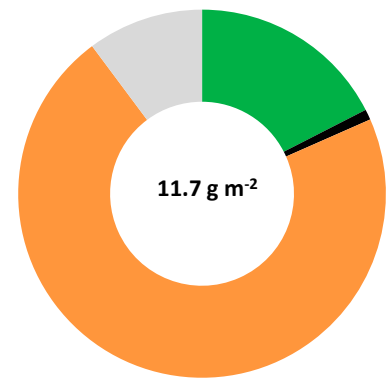

2018-2019

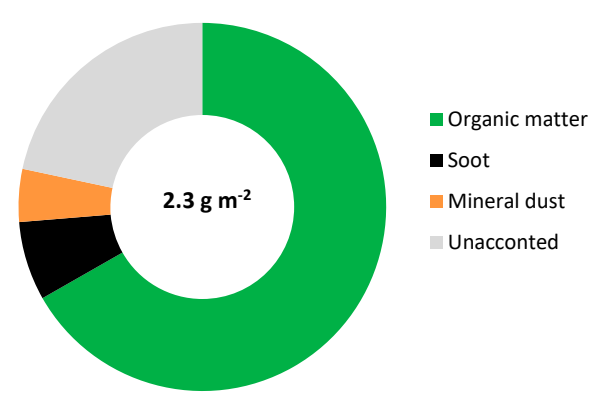

Figure 4. Chemical composition of the accumulated insoluble deposition during cold-seasons (from beginning of November to end May) at ORD (Central Pyrenees, Spain), in $\mathrm{g} \mathrm{m}^{-2}$.

As African dust particles emerge as the main aerosol source in our region, two of the most intense African dust events were doubly analyzed. After the occurrence of the November 2016 and February 2017 dust deposition events, the corresponding dust layers were sampled (Figure 5). The inorganic chemical characterization of snow dust samples (SDS) and their corresponding atmospheric deposition samples are presented in Table 1 . Aerosol composition during dust events was dominated by $\mathrm{SiO}_{2}$, $\mathrm{Al}_{2} \mathrm{O}_{3}$, and $\mathrm{Fe}_{2} \mathrm{O}_{3}$, with less abundance of other oxides including $\mathrm{K}_{2} \mathrm{O}, \mathrm{MgO}$, or $\mathrm{CaO}$. The study of the ratios between SDS and atmospheric deposition samples reveals a number of features: (1) The clear dominance of dust deposition over other aerosol sources in these cases, as ratios next to 1 are observed for most of elements/oxides; (2) the comparability of the two sampling points in these cases regardless of their different altitude, except for specific anthropogenically related elements such as $\mathrm{Zn}$, $\mathrm{Cd}$ or Se, sometimes enhanced at the ORD site; (3) the fast dissolution of calcite (less intense in the case of dolomite) in atmospheric deposition samples, as revealed by the Ca depletion (less important for $\mathrm{Mg}$ ) in ORD samples with respect to their corresponding in the snowpack.
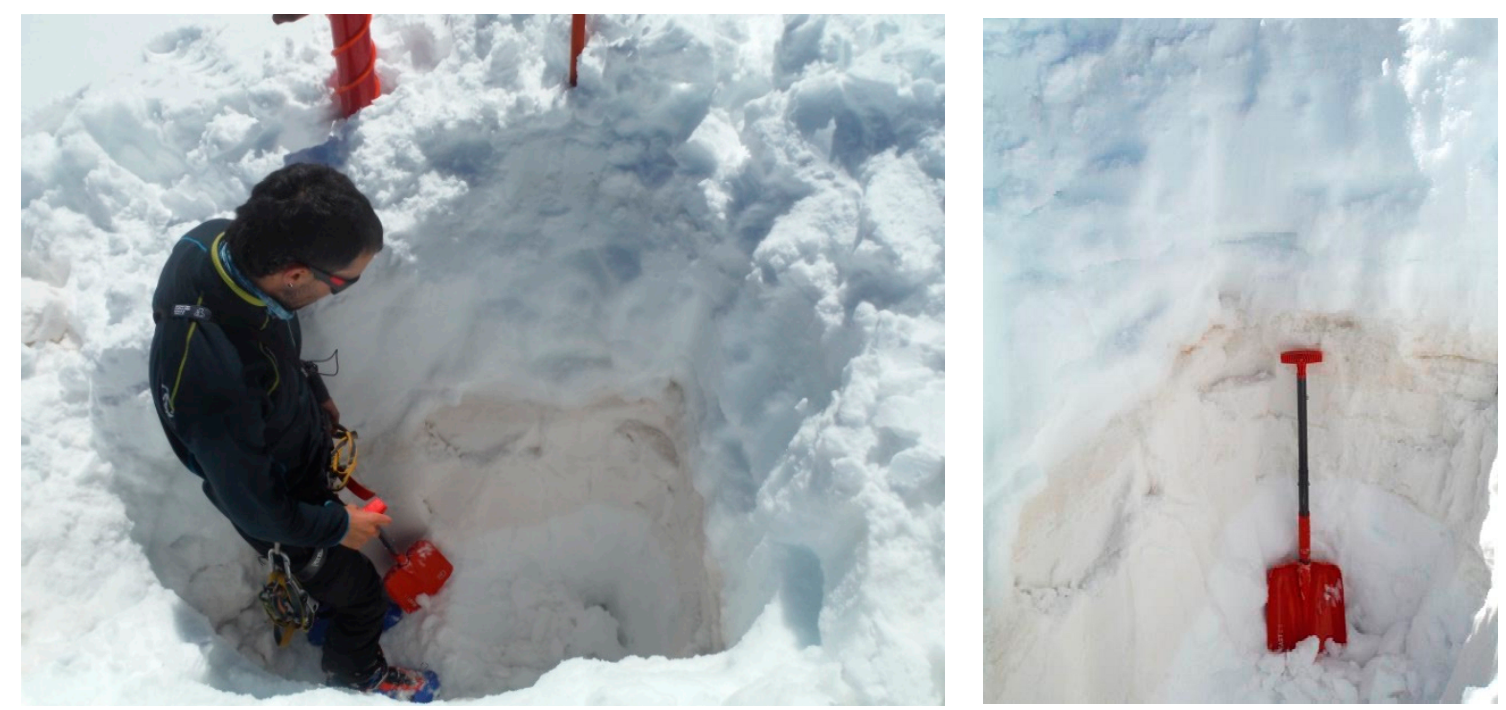

Figure 5. Illustration of the snowpack section after the February 2017 dust event. Sampling site near the Marboré Lake. Photo by M. Bartolomé. 
Table 1. Inorganic composition of two of the most intense Saharan dust events recorded. Snow samples (only dust layer) and atmospheric deposition samples (15-days of accumulation) are shown. Snow samples: SDS1 collected on 24 November 2016; SDS2 collected on 20 February 2017. Sampling at Ordesa: ORD1, from 22 November to 5 December 2016; ORD2, from 31 January to 14 February 2017.

\begin{tabular}{|c|c|c|c|c|c|c|c|}
\hline \multirow{2}{*}{\multicolumn{2}{|c|}{$\begin{array}{c}\text { Major and } \\
\text { Trace Chemicals }\end{array}$}} & \multicolumn{2}{|c|}{ Snow Dust Samples } & \multicolumn{2}{|c|}{$\begin{array}{c}\text { 15-Days } \\
\text { Atmospheric Deposition }\end{array}$} & \multicolumn{2}{|c|}{$\begin{array}{c}\text { Ratio Atmospheric Deposition } \\
\text { Snow Dust Samples }\end{array}$} \\
\hline & & SDS1 & SDS2 & ORD1 & ORD2 & ORD1/SDS1 & ORD2/SDS2 \\
\hline \multirow{9}{*}{$\mathrm{mg} \mathrm{m}^{-2}$} & $\mathrm{SiO}_{2}$ & 2651 & 1597 & 3160 & 1952 & 1.2 & 1.2 \\
\hline & $\mathrm{Al}_{2} \mathrm{O}_{3}$ & 1060 & 639 & 1264 & 781 & 1.2 & 1.2 \\
\hline & $\mathrm{CaO}$ & 594 & 289 & 144 & 97 & 0.2 & 0.3 \\
\hline & $\mathrm{Fe}_{2} \mathrm{O}_{3}$ & 1019 & 592 & 1030 & 624 & 1.0 & 1.1 \\
\hline & $\mathrm{K}_{2} \mathrm{O}$ & 248 & 149 & 427 & 233 & 1.7 & 1.6 \\
\hline & $\mathrm{MgO}$ & 337 & 216 & 273 & 172 & 0.8 & 0.8 \\
\hline & $\mathrm{Na}_{2} \mathrm{O}$ & 176 & 119 & 87 & 47 & 0.5 & 0.4 \\
\hline & $\mathrm{TiO}_{2}$ & 56 & 37 & 27 & 13 & 0.5 & 0.4 \\
\hline & $\mathrm{MnO}$ & 8 & 5 & 8 & 5 & 0.9 & 1.1 \\
\hline \multirow{16}{*}{$\mu \mathrm{g} \mathrm{m} \mathrm{m}^{-2}$} & $\mathrm{Sr}$ & 978 & 583 & 832 & 528 & 0.9 & 0.9 \\
\hline & Be & 18 & 11 & 21 & 9 & 1.1 & 0.8 \\
\hline & $\mathbf{V}$ & 839 & 522 & 894 & 446 & 1.1 & 0.9 \\
\hline & $\mathrm{Cr}$ & 695 & 409 & 733 & 345 & 1.1 & 0.8 \\
\hline & Co & 139 & 80 & 138 & 24 & 1.0 & 0.3 \\
\hline & $\mathrm{Ni}$ & 370 & 211 & 371 & 177 & 1.0 & 0.8 \\
\hline & $\mathrm{Cu}$ & 280 & 163 & 338 & 147 & 1.2 & 0.9 \\
\hline & $\mathrm{Zn}$ & 1368 & 1753 & 7666 & 2588 & 5.6 & 1.5 \\
\hline & As & 79 & 50 & 87 & 42 & 1.1 & 0.8 \\
\hline & Se & 40 & 20 & 61 & 47 & 1.5 & 2.3 \\
\hline & $\mathrm{Cd}$ & 18 & 2 & 8 & 10 & 0.4 & 6.8 \\
\hline & $\mathrm{Sb}$ & 12 & 5 & 14 & 6 & 1.2 & 1.2 \\
\hline & $\mathrm{Ba}$ & 3769 & 2420 & 3658 & 2180 & 1.0 & 0.9 \\
\hline & $\mathrm{Pb}$ & 252 & 154 & 314 & 174 & 1.2 & 1.1 \\
\hline & Th & 114 & 60 & 109 & 59 & 1.0 & 1.0 \\
\hline & $\mathbf{U}$ & 16 & 11 & 19 & 10 & 1.2 & 0.9 \\
\hline \multicolumn{2}{|c|}{$\begin{array}{l}\text { Mineral dust } \\
\quad\left(\mathrm{g} \mathrm{m}^{-2}\right)\end{array}$} & 6.16 & 3.65 & 6.43 & 3.93 & 1.0 & 1.1 \\
\hline
\end{tabular}

\subsubsection{Mineralogical Composition of African Dust}

The mineralogical composition of ORD1 and ORD2 dust samples are shown in Figure 6. Quartz $\left(\mathrm{SiO}_{2}\right)$ and clay minerals dominate the mineralogical composition; followed by feldspars, albite $\left(\mathrm{NaAlSi}_{3} \mathrm{O}_{8}\right)$, and microcline $\left(\mathrm{KAlSi}_{3} \mathrm{O}_{8}\right)$; carbonates, calcite $\left(\mathrm{CaCO}_{3}\right)$, and dolomite $\left(\mathrm{CaMg}\left(\mathrm{CO}_{3}\right)_{2}\right)$; and hematite $\left(\mathrm{Fe}_{2} \mathrm{O}_{3}\right)$. In general, both samples are very similar in terms of geochemical and mineralogical composition.

The main clay minerals determined were illite $\left(\left(\mathrm{K}_{,} \mathrm{H}_{3} \mathrm{O}\right)(\mathrm{Al}, \mathrm{Mg}, \mathrm{Fe})_{2}(\mathrm{Si}, \mathrm{Al})_{4} \mathrm{O}_{10}\left[(\mathrm{OH})_{2},\left(\mathrm{H}_{2} \mathrm{O}\right)\right]\right)$ and kaolinite $\left(\mathrm{Al}_{2} \mathrm{Si}_{2} \mathrm{O}_{5}(\mathrm{OH})_{4}\right)$, with minor proportions of palygorskite $\left(\left(\mathrm{Mg}, \mathrm{Al}_{2} \mathrm{Si}_{4} \mathrm{O}_{10}(\mathrm{OH}) \cdot 4\left(\mathrm{H}_{2} \mathrm{O}\right)\right)\right.$, and only the ORD2 sample reflecting the presence of clinochlore $\left.(\mathrm{Mg}, \mathrm{Al})_{6}(\mathrm{Si}, \mathrm{Al})_{4} \mathrm{O}_{10}(\mathrm{OH})_{8}\right)$. The presence of palygorskite in dust samples is typical in the Mediterranean region, and it is related with the emissions from northwestern regions in the African continent [38].

Regarding carbonates, dolomite appears in both samples whereas calcite was only determined in ORD2. It is well-known that carbonate dissolution is enhanced in atmospheric deposition samples in parallel with the time lapse between dust falling out and sample recovery [39]. This could be the most plausible explanation in our case. This is supported by the geochemical differences between snow dust samples (more enriched in $\mathrm{Ca}$ and $\mathrm{Mg}$ ), taken just after the episode occurred, compared to the corresponding atmospheric samples, which were collected according to a calendar. Regardless of sampling artifacts, calcite+dolomite content in the two samples is estimated in 7-9\% for ORD1 and ORD2, respectively. Hematite, the most abundance iron component in soils, was also identified as the only iron component of both samples, explaining the important $\mathrm{Fe}_{2} \mathrm{O}_{3}$ content retrieved from geochemical analyses $(16 \%)$. Finally, traces of anatase $\left(\mathrm{TiO}_{2}\right)$ were identified in both studied samples, in spite of the relatively low $\mathrm{TiO}_{2}$ content $(<0.5 \%)$. 


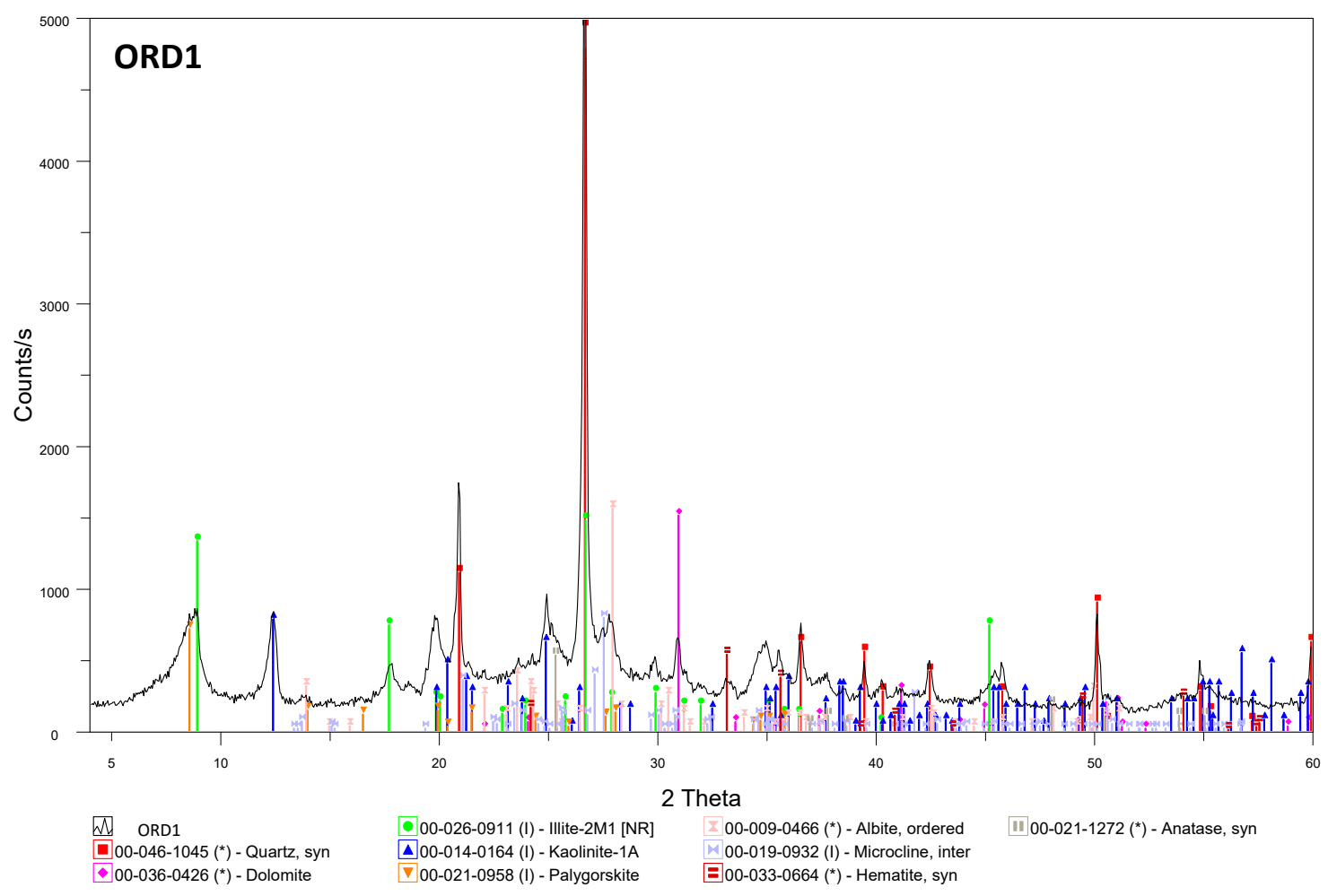

(a)

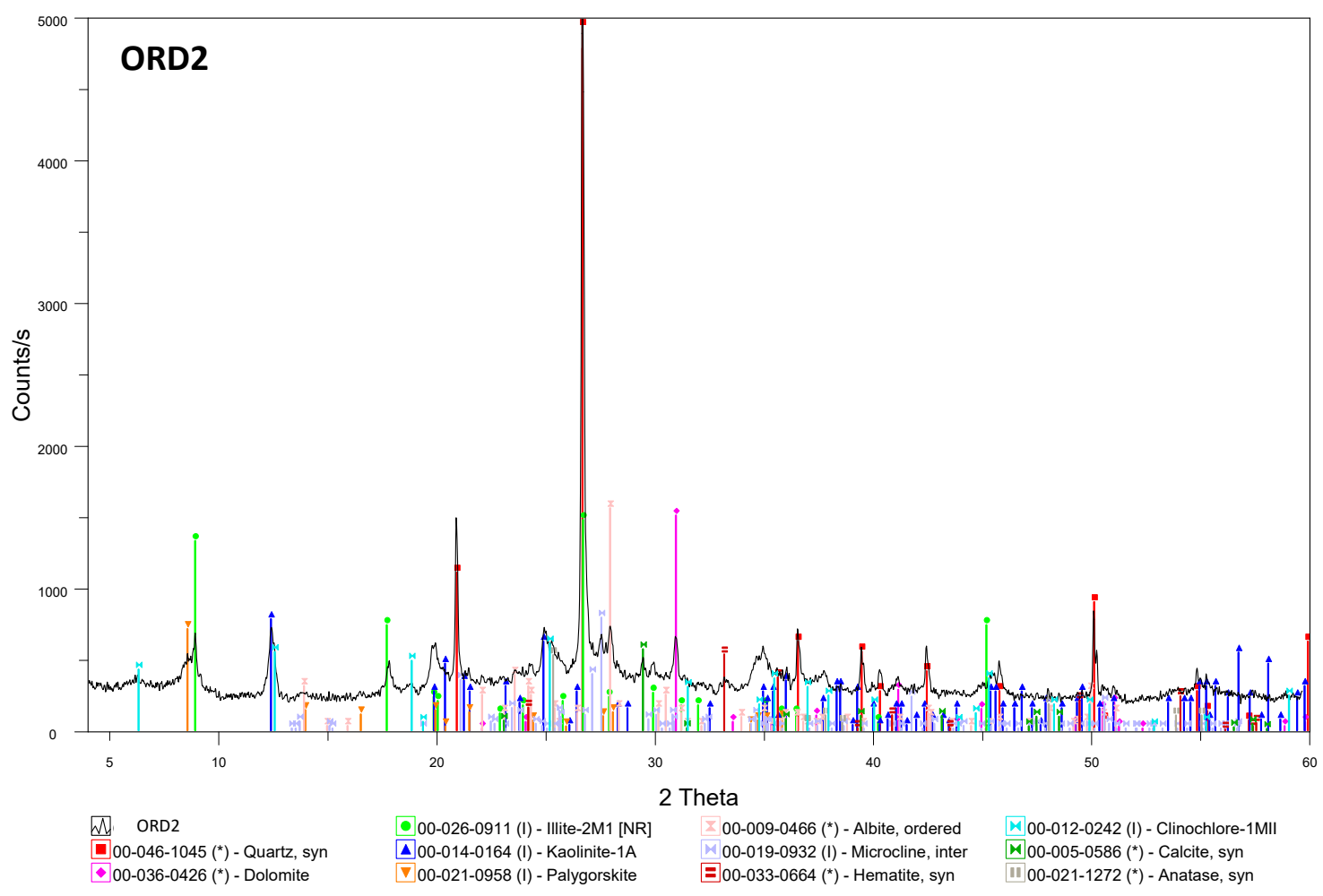

(b)

Figure 6. Mineralogical composition of (a) ORD1; (b) ORD2 dust samples. The $Y$-axis shows the intensity in counts/s and $X$-axis the 2 Theta, which is the angle between incident beam of $X$-ray and the crystallographic reflecting plane. Atmospheric deposition samples: ORD1, from 22 November to 5 December 2016; ORD2, from 31 January to 14 February 2017. 


\subsection{Impact on Snow Albedo}

Figure 2 shows a marked inter-annual variability in climate and snow accumulation in the catchment during the three analyzed years. 2017-2018 season was characterized by wet conditions leading to a deep and long lasting snowpack. The snow season 2018-2019 was characterized by very shallow snowpack with an almost ephemeral nature, with alternation of accumulation and melting events during the whole season. Snowpack during 2016-2017 presented intermediate conditions, with a well-developed snowpack from January to mid-May, but noticeably thinner than the one observed in 2017-2018. Snow surface albedo exhibited a moderate-to-marked decrease at the end of the three snow seasons as a result of snowpack aging and the presence of variable concentrations of LAPs over the snow surface. The shallow snowpack observed on 2018-2019 together with the subsequent melting and accumulation periods, led to some periods with low snow albedo values along the winter.

Figure 7 shows that snow surface reflectance measured in Izas catchment (21 May 2019) is highly variable among 18 points measured at short distance each other. Such variability is mainly driven by the different concentration of snow impurities measured at the snow surface which showed a noticeable spatial heterogeneity at that time of the year. The largest impact of impurities concentration is observed in the spectral region from 1 to $500 \mathrm{~nm}$ range. There are also observed a noticeable dispersion of albedo values in the $1100-1300 \mathrm{~nm}$ range, but variability is not related so clearly to impurities concentration and is probably related to the surface slope variations. Distributed broadband albedo measured in 5 days of 2016-2017 and 2018-2019 seasons (Figure 8) confirm the strong response of the snow reflectance to impurities concentrations. In both years the relationship between albedo and impurities concentration was highly linear $(r=0.71$ and 0.89 respectively), being the slope of the regression slightly steeper during 2018-2019. It is interesting to note that the cloud of points corresponding to 2018-2019 exhibits a positive bias of approximately 0.2-0.3 when compared to the one for 2016-2017. Thus, snow albedo ranges approximately from 0.9 to 0.7 in 2018-2019, and from 0.6 to 0.4 for the common range of impurities concentration that spans from 0 to $0.75 \mathrm{mg} / \mathrm{mL}$.

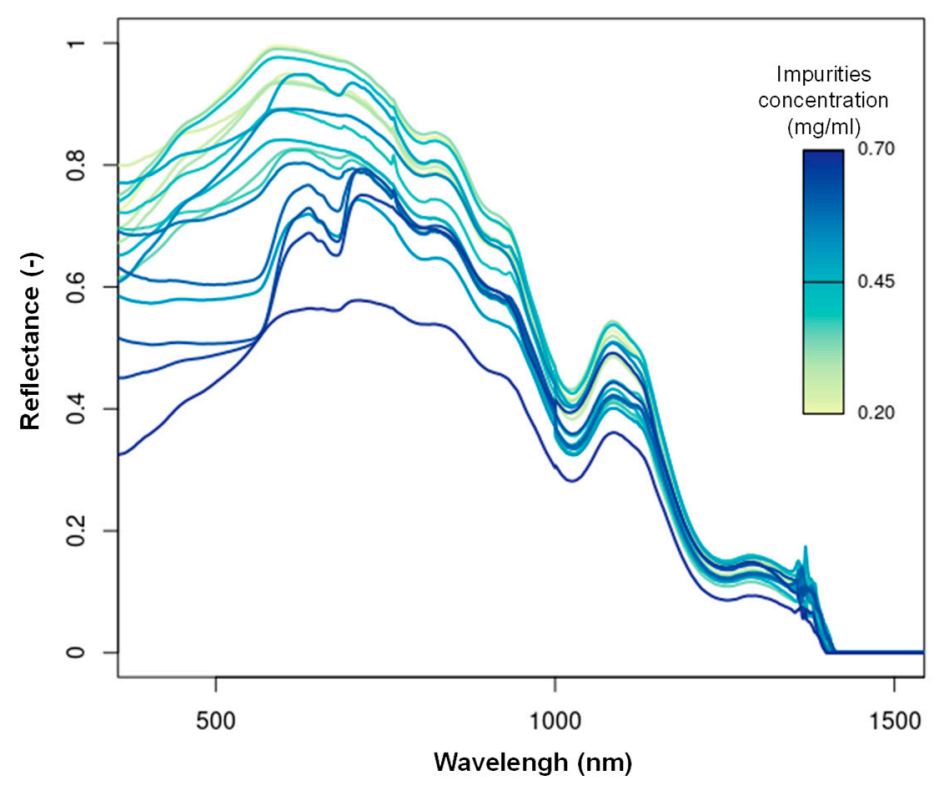

Figure 7. Surface snow spectra observed the 21 May 2019 on different locations in Izas Experimental Catchment. Color bar is indicative of different concentrations of impurities in the snow surface (in $\mathrm{mg} / \mathrm{mL}$ ). 


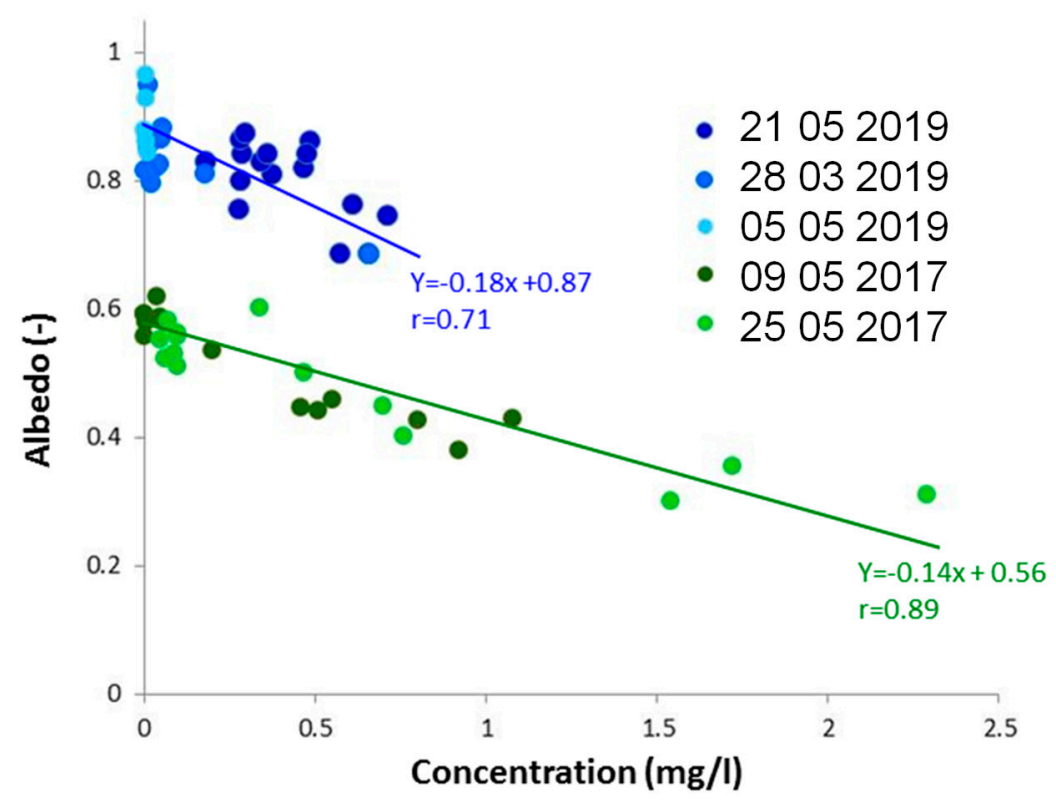

Figure 8. Scatter plot of broadband surface albedo and insoluble material concentration, with the linear adjustment between both variables. Green colored points correspond to 2016-2017 snow season and blue colors to the 2018-2019 snow season observations.

\section{Discussion}

There are different scenarios favoring the transport of African dust toward the Western Mediterranean [40,41], but only under certain conditions dust deposition is magnified over the Central Pyrenees. This is the case of the scenarios 2 and 3 described in [40], associated in most cases with wet deposition and preferentially encountered during the cold season. When these scenarios take place, large amounts of mineral dust particles are usually deposited over the Pyrenees. As discussed in [29], the significance of this phenomenon decreases in parallel toward the west side of the Pyrenees, but their impact toward the East part is still unclear, and their impact northwards (French side) is expected to be lessened.

African dust particles are a mixture of minerals. The Western Mediterranean region receives dust particles from NW African dust sources, especially from Western Sahara, Mauritania and Algeria. As discussed in [38,42], these regions of dust are enriched in carbonates and mafic clay minerals such as palygorskite, with abundant hematite. The results from this study indicate that around $16 \%$ of mineral dust load corresponds to hematite. Bearing in mind that hematite has been identified as the most abundant iron oxide in dust samples and the major light absorbers in the shortwave spectrum in air and snow [43], most of the observed albedo changes could be attributed to the presence of this mineral. An extended study over time focused on the analyses of different snow-samples with different particle loadings and origins would clarify the exact role of individual minerals in this process.

Atmospheric deposition over the Western Mediterranean displays important inter-annual and inter and intra-seasonal variations. Such variability is strongly driven by the incidence of dust plumes from North Africa. Large-scale atmospheric circulation patterns such as the North Atlantic Oscillation may control the export of sub-tropical air masses northwards [44]. Accordingly, negative phases of that index are related to lesser impact of dust plumes over the Central Pyrenees and in general, over the whole NW side of the Mediterranean [23]. When these "low-deposition scenarios" occur, as it happened in 2018-2019 season, atmospheric deposition is shifted toward low amounts of mineral dust and enhanced contributions of organic particles. However, as described in [45], even when considering 30-year time series of aerosol and meteorological data, the African dust deposition-NAO relationship could not be determined because of a large variability of both wind and precipitation. Similarly, it is likely that trends of aerosol load and deposition over short periods like several years to one decade are 
not significant because of the large inter-annual variability. Some studies have revealed an increase in dust deposition episodes over the NE part of Iberia in the past decades [27], while others have shown an important decline in dust contributions over Corsica during the last years [46]. All these studies, however, highlight the importance of dust deposition in terms of overall aerosol flux, and reflect its large variability in space and time [47].

Collected data shows that presence of LAPs on the snow surface strongly influences the temporal and spatial variability of snow surface albedo. Concentration of impurities tends to increase along the melting season since a part of the aerosol deposited onto the snow stays at the surface, in particular the insoluble fraction of the aerosol. However, data from two different years reveal that at similar concentrations of impurities on the snow surface, albedo values are 20 to $30 \%$ higher in 2019. Such differences may be explained by different specific surface area (SSA) of the snow surface, mainly linked to grain size, during the two different years. Previous studies have reported similar magnitudes of the impact of SSA on snow albedo [12,48]. However, it is also interesting to note that the ratio between soluble and insoluble impurities, as well as the inter-annual variability of the fractions of dust, soot and organic matter constituting such LAPs exhibited large differences among both years. Here, we hypothesize that such differences may also impact on the snow albedo through different impacts of both on SSA, but also on the reflectance itself as a consequence of the contrasted mineralogical composition found in the impurities during the different years. Such processes should be considered in further research. In addition, it is necessary to consider that different impacts can exist on snow albedo during the melting period under similar LAP seasonal deposition, depending on the frequency of snowfall events during the melting period that dramatically increases snow albedo temporally; and the air temperature and incoming solar radiation that will affect the metamorphism of snow surface and the evolution of SSA.

\section{Conclusions}

Aerosol deposition in the Central Pyrenees (Spain) is enhanced during cold seasons when extreme desert dust episodes take place. This occurred in two out of the three winter seasons studied. Such dust inputs were recorded from November to April, and insoluble aerosol loadings associated to each event varied from 4.5 to $10.6 \mathrm{~g} \mathrm{~m}^{-2}$.

Chemical composition of insoluble aerosols during cold seasons clearly contrasts when comparing different years. It is shifted toward a prevailing mineral composition when such extreme Saharan dust contributions occurred, but it had an organic signature in absence of these phenomena. Contributions of black carbon aerosols emerged as marginal with respect to mineral dust when such intense dust outbreaks were recorded, but they were comparable to mineral dust during the other winter season.

Mineral composition of dust inputs is dominated by quartz and clay minerals, followed by feldspars, carbonates, and hematite. The last, connected to light absorbing processes, may account for $15 \%$ of the mass loading.

Snow albedo is strongly disturbed when LAPs are found in the surface. We have observed a positive relation between mass loading and snow albedo values, which ranged from 0.9 to 0.7 during the dust-free winter season (2018-2019), and 0.6 to 0.4 during the 2016-2017 dusty season, for the common range of impurities concentration that spans from 0 to $0.75 \mathrm{mg} / \mathrm{mL}$. The chemical nature of these LAPs could play a double role in this sense, directly absorbing part of the incoming radiation but also influencing snow grain sizing.

Author Contributions: Conceptualization, J.P. and J.I.L.-M.; methodology, J.P., J.R. (Jesús Reyes), E.A.-G., M.B., N.M., S.G., J.I.L.-M.; software, J.R. (Jesús Revuelto); formal analysis, J.P., N.M., J.I.L.-M., J.R. (Jesús Revuelto); writing - original draft preparation, J.P. and J.I.L.-M., with contributions of all authors. All authors have read and agreed to the published version of the manuscript.

Funding: “This research was funded by the Spanish Agencia Estatal de Investigación; European Funds for Regional Development, grant number CGL2015-68993-R and by the Fundación Biodiversidad, grant number PRCV00464". The Spanish Ministry of Science and Innovation (Project CEX2018-000794-S; Severo Ochoa) and the 
Generalitat de Catalunya (project number: AGAUR 2017 SGR41) provided support for the indirect costs for the Institute of Environmental Assessment and Water Research (IDAEA-CSIC).

Acknowledgments: This work has been possible thanks to financial support via DONAIRE and AERONIVAL projects. We would like to thank the Ordesa y Monte Perdido National Park director, technicians and other staff for their support. Maps generated for this article have been produced by the QGIS (http://qgis.osgeo.org) Development Team (2018), v 3.10, by using the OpenStreetMap Hydda base copy.

Conflicts of Interest: The authors declare no conflict of interest.

Data Availability: Data from this article will be provided to anyone interested upon request to the authors.

\section{References}

1. Pöschl, U. Atmospheric aerosols: Composition, transformation, climate and health effects. Angew. Chem. Int. Ed. Engl. 2005, 44, 7520-7540. [CrossRef] [PubMed]

2. Pope, C.A., III; Dockery, D.W. Health Effects of Fine Particulate Air Pollution: Lines that Connect. J. Air Waste Manag. Assoc. 2006, 56, 709-742. [CrossRef]

3. Mahowald, N. Aerosol indirect effect on biogeochemical cycles and climate. Science 2011, 334, 794-796. [CrossRef] [PubMed]

4. Camarero, L.; Catalan, J. Atmospheric phosphorus deposition may cause lakes to revert from phosphorus limitation back to nitrogen limitation. Nat. Commun. 2012, 3, 1118. [CrossRef] [PubMed]

5. Bond, T.C.; Doherty, S.J.; Fahey, D.W.; Forster, P.M.; Berntsen, T.; DeAngelo, B.J.; Flanner, M.G.; Ghan, S.; Kärcher, B.; Koch, D.; et al. Bounding the role of black carbon in the climate system: A scientific assessment. J. Geophys. Res. Atmos. 2013, 118, 5380-5552. [CrossRef]

6. IPCC. Intergovernmental Panel on Climate Change: Working Group I Contribution to the IPCC Fifth Assessment Report Climate Change 2013: The Physical Science Basis; IPCC Cambridge University Press: Cambridge, UK; New York, NY, USA, 2013; p. 1535.

7. Hadley, O.; Kirchstetter, T. Black-carbon reduction of snow albedo. Nat. Clim. Chang. 2012, 2, 437-440. [CrossRef]

8. Qu, B.; Ming, J.; Kang, S.-C.; Zhang, G.-S.; Li, Y.-W.; Li, C.-D.; Zhao, S.-Y.; Ji, Z.-M.; Cao, J.-J. The decreasing albedo of the Zhadang glacier on western Nyainqentanglha and the role of light-absorbing impurities. Atmos. Chem. Phys. 2014, 14, 11117-11128. [CrossRef]

9. Shi, T.; Pu, W.; Zhou, Y.; Cui, J.; Zhang, D.; Wang, X. Albedo of black carbon-contaminated snow across northwestern China and the validation with model simulation. J. Geophys. Res. Atmos. 2020, 125, e2019JD032065. [CrossRef]

10. Painter, T.H.; Bryant, A.C.; Skiles, S.M. Radiative forcing by light absorbing impurities in snow from MODIS surface reflectance data. Geophys. Res. Lett. 2012, 39, L17502. [CrossRef]

11. Di Mauro, B.; Fava, F.; Ferrero, L.; Garzonio, R.; Baccolo, G.; Delmonte, B.; Colombo, R. Mineral dust impact on snow radiative properties in the European Alps combining ground, UAV, and satellite observations. J. Geophys. Res. Atmos. 2015, 120, 6080-6097. [CrossRef]

12. Skiles, S.M.; Flanner, M.; Cook, J.M.; Dumont, M.; Painter, T.H. Radiative forcing by light-absorbing particles in snow. Nat. Clim. Chang. 2018, 8, 964-971. [CrossRef]

13. Painter, T.H.; Barrett, A.P.; Landry, C.C.; Neff, J.C.; Cassidy, M.P.; Lawrence, C.R.; McBride, K.E.; Farmer, G.L. Impact of disturbed desert soils on duration of mountain snow cover. Geophys. Res. Lett. 2007, 34, L12502. [CrossRef]

14. Painter, T.H.; Deems, J.S.; Belnap, J.; Hamlet, A.F.; Landry, C.C.; Udall, B. Response of Colorado River runoff to dust radiative forcing in snow. Proc. Natl. Acad. Sci. USA 2010, 107, 17125-17130. [CrossRef] [PubMed]

15. Skiles, S.; Painter, T. Daily evolution in dust and black carbon content, snow grain size, and snow albedo during snowmelt, Rocky Mountains, Colorado. J. Glaciol. 2017, 63, 118-132. [CrossRef]

16. Tuzet, F.; Dumont, M.; Picard, G.; Lamare, M.; Voisin, D.; Nabat, P.; Lafaysse, M.; Larue, F.; Revuelto, J.; Arnaud, L. Quantification of the radiative impact of light-absorbing particles during two contrasted snow seasons at Col du Lautaret (2058 m a.s.l., French Alps). Cryosphere Discuss 2020, 1-38. [CrossRef]

17. Usha, K.H.; Nair, V.S.; Babu, S.S. Modeling of aerosol induced snow albedo feedbacks over the Himalayas and its implications on regional climate. Clim. Dyn. 2020, 54, 4191-4210. [CrossRef] 
18. Pere, J.C.; Colette, A.; Dubuisson, P.; Bessagnet, B.; Mallet, M.; Pont, V. Impacts of future air pollution mitigation strategies on the aerosol direct radiative forcing over Europe. Atmos. Environ. 2012, 62, 451-460. [CrossRef]

19. Koch, D.; Bauer, S.E.; Del Genio, A.; Faluvegi, G.; McConnell, J.R.; Menon, S.; Miller, R.L.; Rind, D.; Ruedy, R.; Schmidt, G.A.; et al. Coupled aerosol-chemistry-climate twentieth-century transient model investigation: Trends in short-lived species and climate responses. J. Clim. 2011, 24, 2693-2714. [CrossRef]

20. Krishnan, S.; Ekman, A.M.; Hansson, H.C.; Riipinen, I.; Lewinschal, A.; Wilcox, L.J.; Dallafior, T. The roles of the atmosphere and ocean in driving Arctic warming due to European aerosol reductions. Geophys. Res. Lett. 2020, 47, e2019GL086681. [CrossRef]

21. López-Moreno, J.I.; García-Ruiz, J.M. Influence of snow accumulation and snowmelt on streamflow in the central Spanish Pyrenees/Influence de l'accumulation et de la fonte de la neige sur les écoulements dans les Pyrénées centrales espagnoles. Hydrolog. Sci. J. 2004, 49, 802. [CrossRef]

22. Querol, X.; Pey, J.; Pandolfi, M.; Alastuey, A.; Cusack, M.; Moreno, T.; Viana, M.; Mihalopoulos, N.; Kallos, G.; Kleanthous, S. African dust contributions to mean ambient PM10 levels across the Mediterranean Basin. Atmos. Environ. 2009, 43, 4266-4277. [CrossRef]

23. Pey, J.; Querol, X.; Alastuey, A.; Forastiere, F.; Stafoggia, M. African dust outbreaks over the Mediterranean Basin during 2001-2011: PM10 concentrations, phenomenology and trends, and its relation with synoptic and mesoscale meteorology. Atmos. Chem. Phys. 2013, 13, 1395-1410. [CrossRef]

24. Àvila, A.; Rodà, F. Red rains as major contributors of nutrients and alkalinity to terrestrial ecosystems at Montseny (NE Spain). Orsis 1999, 6, 215-229.

25. Cáliz, J.; Triadó-Margarit, X.; Camarero, L.; Casamayor, E.O. A long-term survey unveils strong seasonal patterns in the airborne microbiome coupled to general and regional atmospheric circulations. Proc. Natl. Acad. Sci. USA 2018, 115, 12229-12234. [CrossRef]

26. Stafoggia, M.; Zauli-Sajani, S.; Pey, J.; Samoli, E.; Alessandrini, E.; Stafoggia, M.; Zauli-Sajani, S.; Pey, J.; Samoli, E.; Alessandrini, E.; et al. Desert Dust outbreaks in southern europe: contribution to daily pm10 concentrations and short-term associations with mortality and hospital admissions. Environ. Health Perspect. 2016, 124, 413-419. [CrossRef]

27. Àvila, A.; Peñuelas, J. Increasing frequency of Saharan rains over northeastern Spain and its ecological consequences. Sci. Total Environ. 1999, 228, 153-156. [CrossRef]

28. Markaki, Z.; Oikonomou, K.; Koçak, M.; Kouvrakis, G.; Chaniotaki, A.; Kubilay, N.; Mihalopoulos, N. Atmospheric deposition of inorganic phosphorus in the Levantine Basin, Eastern Mediterranean: Spatial and temporal variability and its role in seawater productivity. Limnol. Oceanogr. 2003, 48, 1557-1568. [CrossRef]

29. Pey, J.; Larrasoaña, J.C.; Pérez, N.; Cerro, J.C.; Castillo, S.; Tobar, M.L.; de Vergara, A.; Vázquez, I.; Reyes, J.; Mata, M.P.; et al. Phenomenology and geographical gradients of atmospheric deposition in southwestern Europe: Results from a multi-site monitoring network. Sci. Total Environ. 2020, 140745, in press. [CrossRef]

30. Revuelto, J.; Azorin-Molina, C.; Alonso-González, E.; Sanmiguel-Vallelado, A.; Navarro-Serrano, F.; Rico, I.; López-Moreno, J.I. Meteorological and snow distribution data in the Izas Experimental Catchment (Spanish Pyrenees) from 2011 to 2017. Earth Syst. Sci. Data 2017, 9, 993-1005. [CrossRef]

31. Querol, X.; Pey, J.; Minguillón, M.C.; Pérez, N.; Alastuey, A.; Viana, M.; Moreno, T.; Bernabé, R.M.; Blanco, S.; Cárdenas, B.; et al. PM speciation and sources in Mexico during the MILAGRO-2006 Campaign. Atmos. Chem. Phys. 2018, 8, 111-128. [CrossRef]

32. Alastuey, A.; Querol, X.; Aas, W.; Lucarelli, F.; Pérez, N.; Moreno, T.; Cavalli, F.; Areskoug, H.; Balan, V.; Catrambone, M.; et al. Geochemistry of PM10 over Europe during the EMEP intensive measurement periods in summer 2012 and winter 2013. Atmos. Chem. Phys. 2016, 16, 6107-6129. [CrossRef]

33. Cavalli, F.; Viana, M.; Yttri, K.E.; Genberg, J.; Putaud, J.-P. Toward a standardised thermal-optical protocol for measuring atmospheric organic and elemental carbon: The EUSAAR protocol. Atmos. Meas. Tech. 2010, 3, 79-89. [CrossRef]

34. Cerro, J.C.; Cerdà, V.; Querol, X.; Alastuey, A.; Bujosa, C.; Pey, J. Variability of air pollutants, and PM composition and sources at a regional background site in the Balearic Islands: Review of western Mediterranean phenomenology from a 3-year study. Sci. Total Environ. 2020, 717, 137177. [CrossRef] [PubMed]

35. The Powder Diffraction File. International Centre for Diffraction Data. Available online: https://www.icdd. com/pdf-2/ (accessed on 1 September 2020). 
36. Kipp \& Zonen, B.V. CMP/CMA Series Pyranometer and Albedometer, Instruction Manual; Copyright@2016 Kipp \& Zonen B.V.: Delft, The Netherlands, 2016.

37. Picard, G.; Dumont, M.; Lamare, M.; Tuzet, F.; Larue, F.; Pirazzini, R.; Arnaud, L. Spectral albedo measurements over snow-covered slopes: Theory and slope effect corrections. Cryosphere 2020, 14, 1497-1517. [CrossRef]

38. Scheuvens, D.; Schütz, L.; Kandler, K.; Ebert, M.; Weinbruch, S. Bulk composition of northern African dust and its source sediments-A compilation. Earth Sci. Rev. 2013, 116, 170-194. [CrossRef]

39. Fu, Y.; Desboeufs, K.; Vincent, J.; Bon Nguyen, E.; Laurent, B.; Losno, R.; Dulac, F. Estimating chemical composition of atmospheric deposition fluxes from mineral insoluble particles deposition collected in the western Mediterranean region. Atmos. Meas. Tech. 2017, 10, 4389-4401. [CrossRef]

40. Escudero, M.; Castillo, S.; Querol, X.; Avila, A.; Alarcón, M.; Viana, M.M.; Alastuey, A.; Cuevas, E.; Rodríguez, S. Wet and dry African dust episodes over eastern Spain. J. Geophys. Res. 2005, 110, D18S08. [CrossRef]

41. Salvador, P.; Alonso-Pérez, S.; Pey, J.; Artíñano, B.; de Bustos, J.J.; Alastuey, A.; Querol, X. African dust outbreaks over the western Mediterranean Basin: 11-year characterization of atmospheric circulation patterns and dust source areas. Atmos. Chem. Phys. 2014, 14, 6759-6775. [CrossRef]

42. Moreno, T.; Querol, X.; Castillo, S.; Alastuey, A.; Cuevas, E.; Herrmann, L.; Mounkaila, M.; Elvira, J.; Gibbons, W. Geochemical variations in aeolian mineral particles from the Sahara-Sahel Dust Corridor. Chemosphere 2006, 65, 261-270. [CrossRef]

43. Wu, G.; Xu, T.; Zhang, X.; Zhang, C.; Yan, N. The visible spectroscopy of iron oxide minerals in dust particles from ice cores on the Tibetan Plateau. Tellus B Chem. Phys. Meteorol. 2016, 68, 29191. [CrossRef]

44. Moulin, C.; Lambert, C.E.; Dulac, F.; Dayan, U. Control of atmospheric export of dust from North Africa by the North At-lantic Oscillation. Nature 1997, 387, 691-694. [CrossRef]

45. Jerez, S.; Jimenez-Guerrero, P.; Montávez, J.P.; Trigo, R.M. Impact of the North Atlantic Oscillation on European aerosol ground levels through local processes: A seasonal model-based assessment using fixed anthropogenic emissions. Atmos. Chem. Phys. 2013, 13, 11195-11207. [CrossRef]

46. Desboeufs, K.; Bon Nguyen, E.; Chevaillier, S.; Triquet, S.; Dulac, F. Fluxes and sources of nutrient and trace metal atmospheric deposition in the northwestern Mediterranean. Atmos. Chem. Phys. 2018, 18, 14477-14492. [CrossRef]

47. Vincent, J.; Laurent, B.; Losno, R.; Bon Nguyen, E.; Roullet, P.; Sauvage, S.; Chevaillier, S.; Coddeville, P.; Ouboulmane, N.; di Sarra, A.G.; et al. Variability of mineral dust deposition in the western Mediterranean basin and south-east of France. Atmos. Chem. Phys. 2016, 16, 8749-8766. [CrossRef]

48. Dumont, M.; Brun, E.; Picard, G.; Michou, M.; Libois, Q.; Petit, J.-R.; Geyer, M.; Morin, S.; Josse, B. Contribution of light-absorbing impurities in snow to Greenland's darkening since 2009. Nat. Geosci. 2014, 7, 509-512. [CrossRef]

(C) 2020 by the authors. Licensee MDPI, Basel, Switzerland. This article is an open access article distributed under the terms and conditions of the Creative Commons Attribution (CC BY) license (http://creativecommons.org/licenses/by/4.0/). 